\title{
Monitoring of some disinfection by-products in drinking water treatment plants of El-Beheira Governorate, Egypt
}

\author{
Hesham Z. Ibrahim • Mahmoud A. Abu-Shanab
}

Received: 24 March 2013 / Accepted: 1 July 2013/Published online: 14 July 2013

(C) The Author(s) 2013. This article is published with open access at Springerlink.com

\begin{abstract}
Two water treatment plants (Edfina and KomHamada) in El-Beheira Governorate were selected to monitor disinfection by-products (DBPs) concentrations. A 12-month monitoring program from October 2011 to September 2012 was established for measuring some DBPs and some water quality parameters such as temperature, $\mathrm{pH}$, turbidity, total organic carbon (TOC), ammonia and bromide. The concentrations of DBPs were determined by gas chromatography with ECD (GC-ECD). Trihalomethanes (THMs) and chloral hydrate (CH) were commonly seen in all samples collected from Plant 1 (Edfina) and Plant 2 (KomHamada). THMs mean concentrations ranged from 34.5 to $64.6 \mu \mathrm{g} / \mathrm{L}$ and from 28.2 to $52.8 \mu \mathrm{g} / \mathrm{L}$ for Plant 1 and Plant 2 . $\mathrm{CH}$ mean concentrations ranged from 3.3 to $6.76 \mu \mathrm{g} / \mathrm{L}$ and from 2.8 to $3.9 \mu \mathrm{g} / \mathrm{L}$ for Plant 1 and Plant 2, respectively. Dichloroacetonitrile (DCAN) mean concentrations ranged from 1.1 to $2.0 \mu \mathrm{g} / \mathrm{L}$ and from 1.2 to $2.1 \mu \mathrm{g} / \mathrm{L}$ for Plant 1 and Plant 2, respectively. Chloropicrin (CP) was detected in Plant 1 only with mean concentration ranging from 0.91 to $1.1 \mu \mathrm{g} / \mathrm{L}$. Trichloroacetonitrile (TCAN) and dibromoacetonitrile (DBAN) were below the limit of quantification (LOQ) in all samples. Higher concentrations of THMs were measured in summer and spring as compared to winter. DBPs concentrations were higher in Plant 1 than in Plant 2. The DBPs levels in all samples collected from Edfina and Kom-
\end{abstract}

\section{H. Z. Ibrahim}

Institute of Graduate Studies and Research, Alexandria

University, 163, Horreya Avenue, Chatby, P.O. Box 832,

21526 Alexandria, Egypt

e-mail: hz_ibrahim@yahoo.com

M. A. Abu-Shanab ( $\square)$

Central Laboratory of Drinking Water in Beheira Water

Company, El-Beheira, Egypt

e-mail: m_shanab83@yahoo.com
Hamada were generally below the guideline values set by the Egyptian Health Minister in 2007.

Keywords Disinfection by-products - Drinking water . Water quality $\cdot$ Treatment plant $\cdot$ Trihalomethanes $\cdot$ Egypt

\section{Introduction}

Chlorine is currently the most reliable chemical disinfectant used for water disinfection. Chlorine is one of the most commonly used disinfectants in water treatment due to its low cost, easy operation and especially its high efficiency in killing pathogenic microorganisms, but has been reported to form disinfection by-products (DBPs) which are suspected to be human carcinogens (Woo et al. 2002; Hu et al. 2010).

THMs consist of several methane derivative compounds and the four chemical species, comprise chloroform (CF), bromodichloromethane (BDCM), dibromochloromethane (DBCM) and bromoform (BF). THMs were suspected to cause not only cancer but also liver and kidney damage, retarded fetus growth, birth defects and possibly miscarriage (Wright et al. 2004). The US Department of Health and Human Services has determined that chloroform may be anticipated to be a carcinogen. Also, it has been shown that dibromochloromethane and bromoform could damage the nervous system (USEPA 2001). Though the reported concentrations of halonitromethanes (HNMs) were much lower than THMs and HAAs and have not been regulated, cytotoxicity and genotoxicity posed by HNMs are comparable or even higher as compared to THMs and HAAs (Richardson et al. 2007). To minimize the risk of cancer, the United States Environmental Protection Agency (USEPA) and the World Health Organization (WHO) have introduced regulations for levels of some DBPs in drinking water. USEPA regulation for THMs 
concentrations was set at $80 \mu \mathrm{g} / \mathrm{L}$ (USEPA 2001). WHO has suggested a provisional guideline value of $20 \mu \mathrm{g} / \mathrm{L}$ for DCAN, while DBAN guideline value was set at $70 \mu \mathrm{g} / \mathrm{L}$ (WHO 2008). The MCL for THMs compounds in Egypt was set at $100 \mu \mathrm{g} / \mathrm{L}$, while $\mathrm{CH}$, TCAN, DCAN and DBAN were set at 10, 1, 20 and $70 \mu \mathrm{g} / \mathrm{L}$, respectively (Ministry of Health, 2007).

THMs concentrations were investigated in Egypt. Hassan et al. (1996) determined the range of THMs in Alexandria city in Egypt. The detected range of THMs was 49.6-67.3 $\mu \mathrm{g} / \mathrm{L}$. Chloroform and dichlorobromomethane constitute the major fraction of THMs (36.86 and $35.14 \%$, respectively). Chlorodibromomethane was detected in lower concentration $(25.09 \%)$, while bromoform was found only in trace amounts (2.91\%). Geriesh et al. (2008) studied the concentration of the THMs in eight water treatment plants along Ismailia Canal. THMs concentration ranged from 52 to $112 \mu \mathrm{g} / \mathrm{L}$. It is noticed that the concentrations of THMs are remarkably increased during winter season in all of the examined treatment units, which may be attributed to the flourishing of microbiological life during this low stage of the canal water and increasing of the effluent income to its course.

In Egypt, the main focus of the disinfection by-products is THMs. Only limited researches are conducted on other DBPs such as haloacetonitriles, haloketones, chloropicrin and chloral hydrate. The objective of this study was to monitor the levels of disinfection by-products (DBPs) and other water quality parameters such as $\mathrm{pH}$, turbidity, alkalinity, TOC, bromide and ammonia in raw and treated water from a treatment plant in Beheira Governorate, Egypt and compared with the maximum contaminant level (MCL).

\section{Materials and methods}

\section{Sampling}

Sampling was conducted monthly between the 10th and 20th each sampling day from October 2011 to September 2012 from two selected treatment plants in Beheira Governorate, Egypt. These plants are Edfina plant (Plant 1) and KomHamada plant (Plant 2). These treatment plants were selected to cover different points of surface water in Beheira Governorate. Chlorine disinfection and conventional treatment processes are used in both plants. Conventional treatment processes phases were prechlorination, flocculation, sedimentation, filtration and postchlorination. The prechlorination was applied in the coagulation channels and the postchlorination was applied before the entrance of water to finished water reservoir in the distribution system.

Monthly results expressed as an average for three replicates of samples. The sampling period was chosen to cover the seasonal variations during one year and all operational changes. Raw water samples were collected from the entrance of surface water to the plant, while the treated samples were collected from the finished treated water tank; 144 samples were performed during this study (2 samples for each plant (raw, finished samples) $\times 3$ replicates $\times 2$ plants $\times 12$ months).

Samples were collected in 1 liter plastic bottle for measurement of water quality parameters such as $\mathrm{pH}$, turbidity, alkalinity, ammonia and bromide; $60 \mathrm{~mL}$ amber glass vials were used to collect samples for DBPs analysis. Temperature, residual chlorine and $\mathrm{pH}$ were measured in the field immediately.

\section{Analytical procedures}

All measurements were carried out according to the Standard Methods for the Examination of Water and Waste Water (APHA, AWWA, WEF, 2005). All chemicals and reagents were purchased from $\mathrm{HACH}$, Sigma-Aldrich, Chemlab, Merck, Scharlau and Panreac.

Temperature and $\mathrm{pH}$ were measured for surface and treated water using portable $\mathrm{HACH}$ multi-parameter. Residual chlorine was measured for treated water by photometric method (S.M. 4500-Cl G) (APHA, AWWA, WEF, 2005 using $\mathrm{HACH}$ colorimetric.

Turbidity was measured for surface and treated water using HACH $2100 \mathrm{~N}$ turbidity meter (S.M.2130B) (APHA, AWWA, WEF, 2005). Ammonia and bromide were determined by Dionex-600 ion chromatography equipped with electrochemical detector (ECD-50), isocratic pump (IP25) using instrument manual. Ammonia and bromide were determined for surface and treated water.

Analysis of total organic carbon (TOC)

TOC analysis was performed according to (S.M. 5310B) (APHA, AWWA, WEF, 2005) for raw and treated water samples. TOC was analyzed with TOC Analyzer (TekmarDohrmann Apollo 9000). The samples were acidified to a $\mathrm{pH}$ less than 2 by phosphoric acid and then introduced into the instrument.

TOC removal calculated as follows:

$$
\left(1-\left(\frac{\text { treated water TOC }}{\text { source water TOC }}\right)\right) \times 100
$$

Analysis of DBPs

Trihalomethanes (chloroform, bromodichloromethane, chlorodibromomethane, and bromoform), haloacetonitriles (HANs) (trichloroacetonitrile, dichloroacetonitrile, dibromoacetonitrile), chloropicrin, 1,1,1-trichloropropanone 
Table 1 LOQ, RSD \%, Recovery and MU for DBPs analysis

\begin{tabular}{lllll}
\hline Compound & LOQ & RSD \% & Recovery \% & MU \\
\hline Chloroform & 1 & 5 & $85-117$ & $15 \%$ \\
Bromodichloromethane & 0.5 & 6 & $82-116$ & \\
Dibromochloromethane & 0.5 & 6 & $88-114$ & \\
Bromoform & 0.2 & 7 & $84-116$ & \\
Trichloroacetonitrile & 0.1 & 5 & $84-120$ & \\
Dichloroacetonitrile & 1 & 8 & $83-114$ & \\
Dibromoacetonitrile & 1 & 9 & $85-117$ & \\
Chloral hydrate & 0.2 & 7 & $85-115$ & \\
Chloropicrin & 0.5 & 4 & $84-116$ & \\
1,1,1-Trichloropropane & 0.5 & 6 & $82-116$ & \\
\hline
\end{tabular}

$L O Q$ limit of quantification, $R S D \%$ relative standard deviation, $M U$ method uncertainty

and chloral hydrate were analyzed as described in USEPA method 551.1 (USEPA Method 551.1, 1995).

$1,000 \mu \mathrm{g} \backslash \mathrm{L}$ individual stock standard solutions of DBPs compounds were diluted to perform a calibration curve. Phosphate buffer prepared from $1 \%$ sodium phosphate dibasic $\left(\mathrm{Na}_{2} \mathrm{HPO}_{4}\right) / 99 \%$ potassium phosphate monobasic $\left(\mathrm{KH}_{2} \mathrm{PO}_{4}\right)$ used to lower the sample matrix $\mathrm{pH}$ to 4.8-5.5. Ammonium chloride $\left(\mathrm{NH}_{4} \mathrm{Cl}\right)$ was used as a dechlorinating agent. Methyl tert-butyl ether (MTBE) was used for extraction.

From the sample, $10 \mathrm{~mL}$ was removed. The $\mathrm{pH}$ was checked in this $10 \mathrm{~mL}$ aliquot to verify that it is within a $\mathrm{pH}$ range of 4.5 and 5.5. $3.0 \mathrm{~mL}$ of MTBE was added, and then $8 \mathrm{gm}$ of sodium chloride was added to each vial containing the water samples. The sample was shaken vigorously for exactly $2 \mathrm{~min}$. Water and solvent phases were allowed to separate approximately for $2 \mathrm{~min}$. Then $1.5 \mathrm{~mL}$ of solvent phase was transferred to the $2 \mathrm{~mL}$ auto sampler vial.

An Agilent 7890A Gas Chromatograph with an electron capture detector (ECD) with DB-1.30 $\mathrm{m} \times 0.25 \mathrm{~mm} \times$ $1.00 \mu \mathrm{m}$ capillary column was used for identification and quantification of DBPs. GC conditions, injection temperature was $220^{\circ} \mathrm{C}$. ECD temperature was $300{ }^{\circ} \mathrm{C}$. Column temperature program was $35^{\circ} \mathrm{C}$ held for $9 \mathrm{~min}$, then a $1{ }^{\circ} \mathrm{C}$ per minute increase to $40{ }^{\circ} \mathrm{C}$ which was maintained for 3 min, and finally a $6{ }^{\circ} \mathrm{C}$ per minute increase until a temperature of $150^{\circ} \mathrm{C}$ was reached, which was held for $1 \mathrm{~min}$. The injection was splitless with a set time of $0.5 \mathrm{~min}$. Flow was set at $24.8 \mathrm{~cm} / \mathrm{sec}$ linear velocity at $150{ }^{\circ} \mathrm{C}$.

Method validation and uncertainty

The validation procedure including limit of quantification (LOQ), recovery $(\% R)$ and relative standard deviation (\% RSD) based on EURACHEM Guide for method validation (EURACHEM Guide 1998). All results are shown in Table 1. The mean recovery ranged from 82 to $120 \%$. The mean RSD ranged from 4 to $9 \%$. From these accuracy and precision results, method uncertainty estimated based on EURACHEM for quantifying uncertainty (EURACHEM 2000).

Calibration and quality control

- Before processing any samples, a blank sample was analyzed to demonstrate that all glassware and reagent interferences are under control. Prepared by adding buffer/dechlorinating agent mixture to reagent water, and then extract and analyze like samples.

- A calibration curve was set at five calibration standard levels.

- As a continuing calibration check, two calibration standards at different concentration levels analyzed at the beginning and the end of sample set.

- Surrogate standard (decafluorobiphenyl) injected in each sample to measure extraction efficiency with accepted recovery up to $20 \%$.

\section{Results and discussion}

Water quality characteristics

Bromide was below LOQ $(70 \mu \mathrm{g} / \mathrm{L})$ in all samples. Water quality parameters of raw and treated water of Plant 1 and Plant 2 are summarized in Tables 2 and 3. Raw water $\mathrm{pH}$ ranged from 7.32 to 8.1 and from 7.5 to 8.25 for Plant 1 and Plant 2, respectively. For Plant 1 , the maximum average value of $\mathrm{pH}$ (7.72) for raw water was found in winter, while minimum average value (7.5) was in spring. For Plant 2, the maximum average value (8.1) for raw water was reported in autumn, while minimum average value (7.53) was in spring. Treated water $\mathrm{pH}$ ranged from 6.83 to 7.4 and from 7.5 to 8.25 for Plant 1 and Plant 2, respectively. For Plant 1, the maximum average value (7.22) for treated water was reported in summer, while the minimum average value (7.0) was in spring. There was no definite variation between seasons. For Plant 2, the maximum average value (7.6) for treated water was reported in autumn, while the minimum average value (7.2) was in winter.

Raw water turbidity results ranged from 2.1 to 3.9 NTU and from 2.2 to $15.3 \mathrm{NTU}$ for Plant 1 and Plant 2, respectively. For Plant 1 , the maximum average value (3.71 NTU) was reported in spring, while the minimum average value (2.3 NTU) was in autumn. For Plant 2, the maximum average value (12 NTU) was reported in autumn, while the minimum average value (7.4 NTU) was in spring. All results of treated water turbidity were below 1 NTU.

Raw water alkalinity results ranged from 150 to $240 \mathrm{mg} / \mathrm{L}$ and 124 to $180 \mathrm{mg} / \mathrm{L}$ for Plant 1 and Plant 2, respectively. For Plant 1 , the maximum average value $(213 \mathrm{mg} / \mathrm{L})$ was 
Table 2 Raw water characteristics for Plant 1 and Plant 2

\begin{tabular}{|c|c|c|c|c|c|c|c|c|}
\hline & \multicolumn{4}{|c|}{ Plant 1} & \multicolumn{4}{|c|}{ Plant 2} \\
\hline & Mean & $\mathrm{SD}$ & MAX & MIN & Mean & SD & MAX & MIN \\
\hline Temp $\left({ }^{\circ} \mathrm{C}\right)$ & 18.75 & 4.02 & 24.70 & 12.50 & 18.38 & 4.06 & 25.10 & 11.50 \\
\hline $\mathrm{pH}$ & 7.66 & 0.25 & 8.10 & 7.32 & 7.86 & 0.23 & 8.25 & 7.50 \\
\hline Turbidity (NTU) & 3.25 & 0.63 & 3.90 & 2.10 & 9.13 & 3.37 & 15.30 & 2.17 \\
\hline TOC (mg/L) & 6.01 & 0.77 & 7.60 & 4.80 & 7.21 & 1.39 & 9.00 & 4.80 \\
\hline $\mathrm{NH}_{3} \quad(\mathrm{mg} / \mathrm{L})$ & 1.45 & 1.33 & 5.10 & 0.51 & 0.37 & 0.08 & 0.45 & 0.30 \\
\hline
\end{tabular}

Table 3 Treated water characteristics for Plant 1 and Plant 2

\begin{tabular}{|c|c|c|c|c|c|c|c|c|}
\hline & \multicolumn{4}{|l|}{ Plant 1} & \multicolumn{4}{|c|}{ Plant 2} \\
\hline & Mean & SD & MAX & MIN & Mean & SD & MAX & MIN \\
\hline Temp $\left({ }^{\circ} \mathrm{C}\right)$ & 18.97 & 3.99 & 24.80 & 12.90 & 18.43 & 4.13 & 25.30 & 11.40 \\
\hline $\mathrm{pH}$ & 7.14 & 0.18 & 7.40 & 6.83 & 7.35 & 0.21 & 7.86 & 7.10 \\
\hline Turbidity (NTU) & 0.70 & 0.23 & 1.00 & 0.35 & 0.72 & 0.15 & 1.00 & 0.50 \\
\hline TOC (mg/L) & 4.15 & 0.78 & 5.70 & 2.90 & 4.86 & 1.07 & 6.30 & 3.00 \\
\hline TOC removal $(\%)$ & 31.32 & 5.80 & 43.64 & 25.00 & 32.75 & 6.12 & 45.71 & 27.14 \\
\hline Chlorine dose $(\mathrm{mg} / \mathrm{L})$ & 7.30 & 4.70 & 20.50 & 3.50 & 3.90 & 0.53 & 5.50 & 3.20 \\
\hline Residual chlorine (mg/L) & 1.41 & 0.26 & 1.80 & 0.89 & 1.47 & 0.11 & 1.70 & 1.30 \\
\hline
\end{tabular}

reported in winter, while the minimum average value (165 mg/L) was in spring. For Plant 2, the maximum average value $(163 \mathrm{mg} / \mathrm{L})$ was reported in autumn, while the minimum average value $(132 \mathrm{mg} / \mathrm{L})$ was in spring.

Free residual chlorine results in treated water ranged from 0.89 to $1.8 \mathrm{mg} / \mathrm{L}$ and from 1.3 to $1.7 \mathrm{mg} / \mathrm{L}$ for Plant 1 and Plant 2, respectively. For Plant 1, the maximum average value was $1.6 \mathrm{mg} / \mathrm{L}$ reported in winter, while the minimum average value was $1.2 \mathrm{mg} / \mathrm{L}$ reported in summer. For Plant 2, the maximum average value was $1.6 \mathrm{mg} / \mathrm{L}$ reported in autumn, while the minimum average value was 1.37 reported in summer.

The raw water TOC results ranged from 4.8 to $7.9 \mathrm{mg} / \mathrm{L}$ and 4.8 to $9 \mathrm{mg} / \mathrm{L}$ for Plant 1 and Plant 2, respectively. For Plant 1 , the maximum average value $(6.6 \mathrm{mg} / \mathrm{L})$ was reported in winter. The minimum average value $(5.3 \mathrm{mg} / \mathrm{L})$ was reported in spring. For Plant 2, the maximum average value $(8.5 \mathrm{mg} / \mathrm{L})$ was reported in winter, while the minimum average value $(5.6 \mathrm{mg} / \mathrm{L})$ was in spring. These ranges of TOC are higher than the ranges reported by Geriesh et al. (2008). They reported a range between 2.4 and $5.3 \mathrm{mg} / \mathrm{L}$ in Ismailia Canal in Egypt. They noticed also that the maximum result reported in winter was due to the low stage level of the canal during this season (effluent conditions). The treated water TOC results ranged from 2.9 to $5.7 \mathrm{mg} / \mathrm{L}$ and from 3 to $6.3 \mathrm{mg} / \mathrm{L}$ for Plant 1 and Plant 2, respectively. Table 4 shows the minimum required removal percentage of TOC for conventional treatment assigned by USEPA for different water quality parameters.
Table 4 Required removal of TOC for systems using conventional treatment

\begin{tabular}{llll}
\hline Source-water TOC, $\mathrm{mg} / \mathrm{L}$ & \multicolumn{3}{l}{ Source-water alkalinity, $\mathrm{mg} / \mathrm{L}$ as $\mathrm{CaCO}^{3}$} \\
\cline { 2 - 4 } & $0-60(\%)$ & $\leq 60-120(\%)$ & $>120(\%)$ \\
\hline$>2.0-4.0$ & 35.0 & 25.0 & 15.0 \\
$>4.0-8.0$ & 45.0 & 35.0 & 25.0 \\
$>8.0$ & 50.0 & 40.0 & 30.0 \\
\hline
\end{tabular}

(USEPA 1998)

All results of percentages of TOC removal for Plant 1 and Plant 2 meet these criteria (Table 5).

Raw water ammonia $\left(\mathrm{NH}_{3}\right)$ results ranged from 0.55 to $5.1 \mathrm{mg} / \mathrm{L}$ and 0.3 to $0.45 \mathrm{mg} / \mathrm{L}$ for Plant 1 and Plant 2, respectively. For Plant 1 , the maximum average value $(3.1 \mathrm{mg} / \mathrm{L})$ (Fig. 1) was reported in winter, while the minimum average value $(0.6 \mathrm{mg} / \mathrm{L})$ was reported in summer. For Plant 2, it was detected only in autumn. These ranges are higher than the ranges reported by Othman et al. (2012) in Ismailia Canal in Egypt $(0.07-1.49 \mathrm{mg} / \mathrm{L})$. It was not present in all treated water samples (Fig. 2).

Occurrence and speciation of DBPs

THMs were detected in all samples of Plant 1 and Plant 2. THMs concentrations ranged from 19.9 to $81.4 \mu \mathrm{g} / \mathrm{L}$ and from 18.5 to $59.5 \mu \mathrm{g} / \mathrm{L}$ for Plant 1 and Plant 2, respectively. The maximum average value for Plant 1 was $64.6 \mu \mathrm{g} / \mathrm{L}$. It was reported in spring, while its minimum 
Table 5 The correlation between water quality parameters and DBPs

\begin{tabular}{lrlllll}
\hline & Temp & $\mathrm{pH}$ & Free chlorine & Chlorine dose & TOC & TOC removal \% \\
\hline THMs & 0.87 & 0.23 & -0.44 & 0.345 & 0.232 & -0.21 \\
DCAN & 0.20 & 0.37 & -0.38 & 0.201 & 0.254 & -0.13 \\
CH & 0.58 & 0.29 & -0.28 & 0.435 & 0.297 & -0.15 \\
TCP & -0.33 & 0.33 & -0.06 & 0.105 & 0.152 & -0.06 \\
\hline
\end{tabular}

Fig. 1 Gas chromatography chromatogram for DBPs standard solution

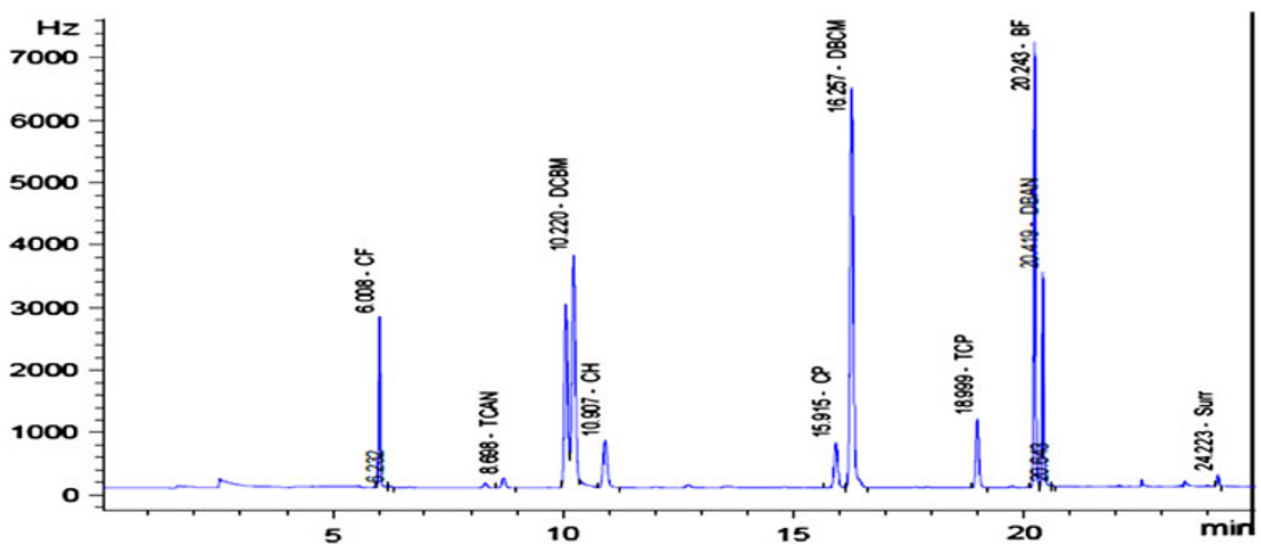

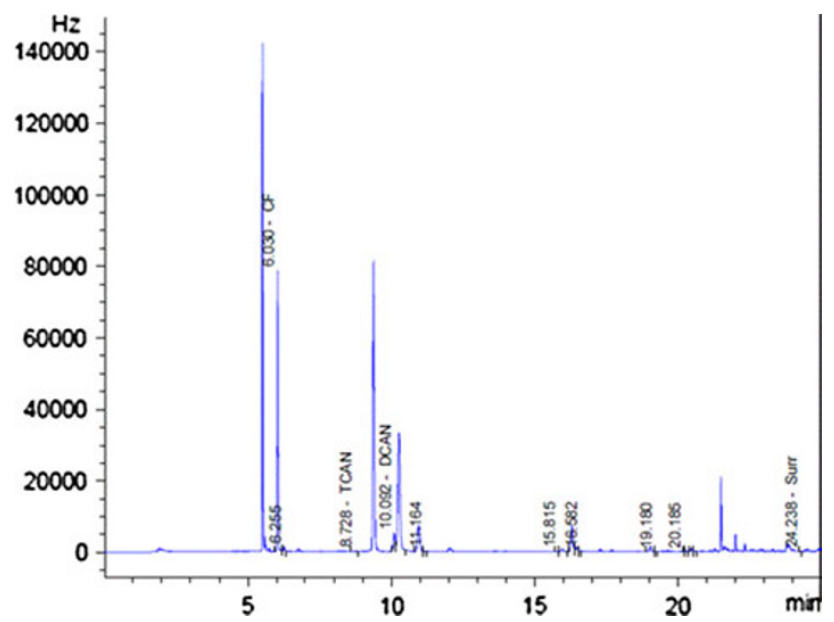

Fig. 2 Gas chromatography chromatogram for DBPs sample

average value was $34.5 \mu \mathrm{g} / \mathrm{L}$. It was reported in winter (Fig. 3). The maximum average value for Plant 2 was $52.8 \mu \mathrm{g} / \mathrm{L}$. It was reported in summer, while the minimum average value was $28.2 \mu \mathrm{g} / \mathrm{L}$. It was reported in winter (Fig. 3). The increase in THMs concentration in spring and summer is related to increase of temperature. This trend is in agreement with what is reported in many researches (Golfinopoulos and Nikolaou 2005; El Shehawy and Awad 2012). El Shehawy and Awad (2012) reported lower maximum value for THMs $(61.4 \mu \mathrm{g} / \mathrm{L})$ in Fayoum, Egypt. They reported that the highest THMs formation occurred in spring and summer while the lowest occurred in winter.

Chloroform was the most abundant THMs species followed by BDCM and BDCM which represent about 54, 33

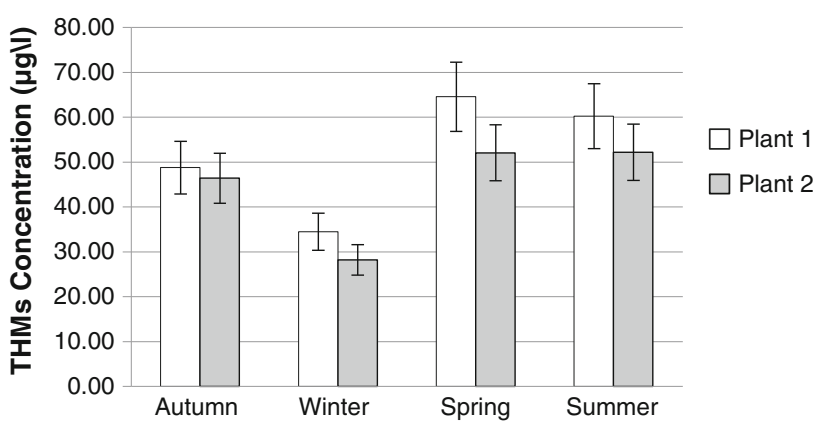

Fig. 3 Seasonal variation of THMs concentrations in Plant 1 and Plant 2

and $13 \%$, in Plant 1 , and 55, 32 and $13 \%$, in Plant 2, respectively (Figs. 4, 5). Bromoform concentrations were below the LOQ in all samples. The percentages of chloroform were lower than those of Ates et al. (2007). They reported that chloroform was found to be the major THMs compound (77.9 \%), followed by BDCM (16.4\%), DBCM (4.9\%), and bromoform (0.9\%).

Other DBPs including halogenated acetonitriles (HANs), 1,1,1-trichloropropanone (TCP), chloral hydrate $(\mathrm{CH})$ and chloropicrin $(\mathrm{CP})$ were usually detected in treated water samples but at lower concentrations from THMs (Figs. 6, 7).

$\mathrm{CH}$ is the most abundant compound after THMs. $\mathrm{CH}$ was detected in all samples of the two plants. $\mathrm{CH}$ ranged from 1.2 to $8.2 \mu \mathrm{g} / \mathrm{L}$ and from 1.8 to $5.2 \mu \mathrm{g} / \mathrm{L}$ for Plant 1 and Plant 2, respectively. The maximum average result in Plant 1 was $6.76 \mu \mathrm{g} / \mathrm{L}$, it was reported in summer. Its minimum average result was $3.3 \mu \mathrm{g} / \mathrm{L}$, it was reported in 


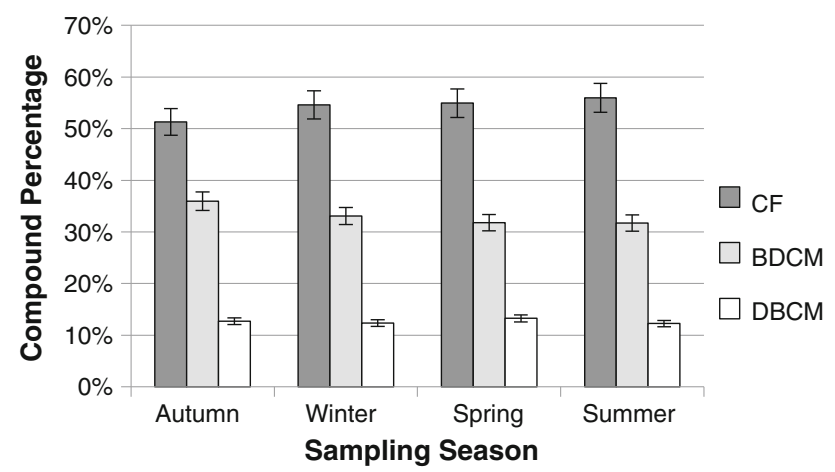

Fig. 4 Speciation of THMs concentration through the seasons for Plant 1

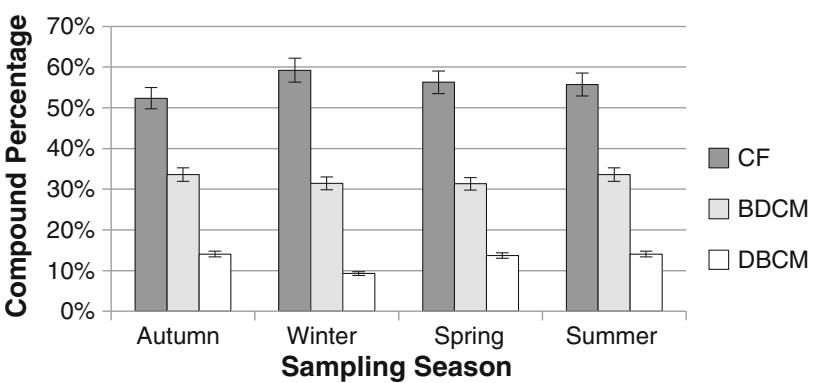

Fig. 5 Speciation of THMs concentration through the seasons for Plant 2

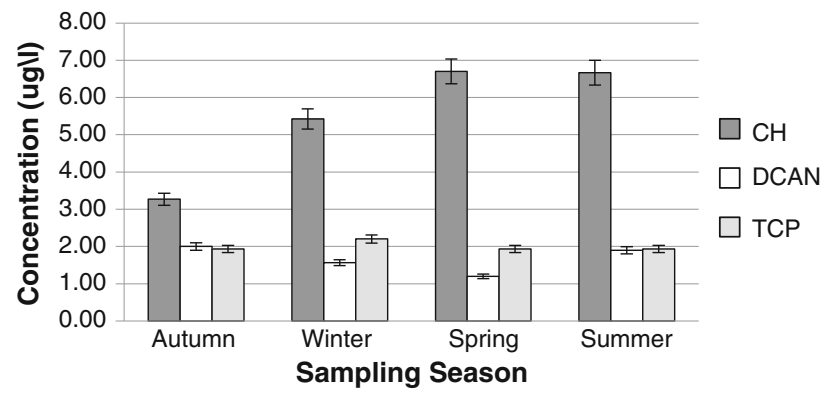

Fig. 6 Seasonal variation of $\mathrm{CH}$, DCAN and TCP in Plant 1

autumn (Fig. 6). The maximum average result in Plant 2 was $3.9 \mu \mathrm{g} / \mathrm{L}$, it was reported in spring. Its minimum average result was $2.8 \mu \mathrm{g} / \mathrm{L}$, it was reported in winter (Fig. 7). These ranges are in agreement with results reported by Lebel et al. (1997) and Wei et al. (2010). CH/ THMs ratios were calculated to compare $\mathrm{CH}$ to THMs. This ratio ranged from 6 to $16 \%$ and from 3 to $10 \%$ for Plant 1 and Plant 2, respectively (Fig. 8). The highest ratio was reported in winter while the lowest one was reported in summer. These ranges are in agreement with Koudjonou et al. (2008).

For HANs, TCAN and DBAN were below LOQ in all samples in Plant 1 and Plant 2. DCAN was found in 75 and $67 \%$ from samples of Plant 1 and Plant 2, respectively.

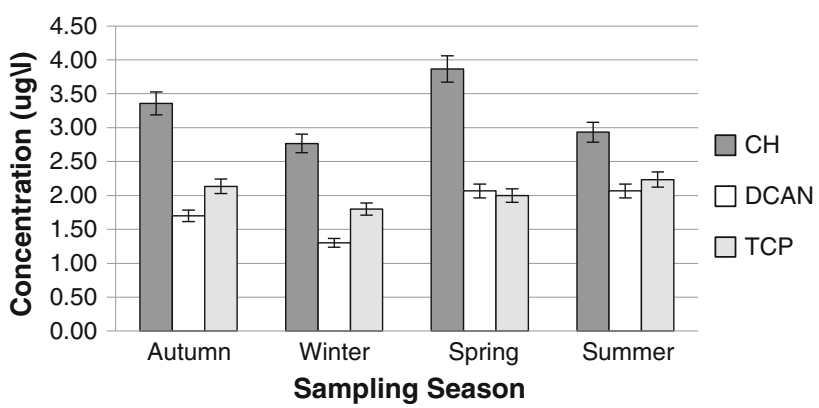

Fig. 7 Seasonal variation of $\mathrm{CH}, \mathrm{DCAN}$ and TCP in Plant 2

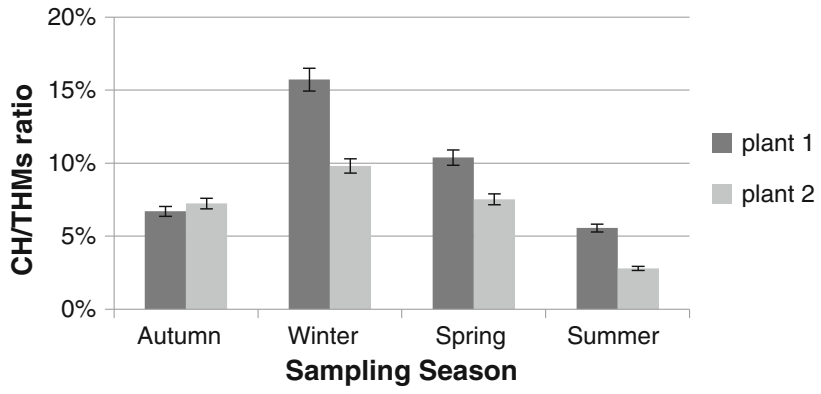

Fig. 8 Seasonal CH/THMs ratio for Plant 1 and Plant 2

The concentration range was from ND to $2.5 \mu \mathrm{g} / \mathrm{L}$ and from ND to $2.4 \mu \mathrm{g} / \mathrm{L}$ for Plant 1 and Plant 2, respectively. These ranges are in agreement with those of Wei et al. (2010); they found the range was from ND to $3.43 \mu \mathrm{g} / \mathrm{L}$.

TCP was detected in all water samples of Plant 1 and Plant 2. The results ranged from 1.5 to $2.4 \mu \mathrm{g} / \mathrm{L}$ and from 1.6 to $2.6 \mu \mathrm{g} / \mathrm{L}$ for Plant 1 and Plant 2, respectively. These values are in agreement with those of Wei et al. (2010) but are lower than the values found in Turkey by Baytak et al. (2008), which reached $7.81 \mu \mathrm{g} / \mathrm{L}$.

$\mathrm{CP}$ was found in about $30 \%$ of the total samples of Plant 1 , while it was not present in all Plant 2 samples. Plant 1 results ranged from ND to $1.3 \mu \mathrm{g} / \mathrm{L}$. These values are lower than values found in Beijing City, China, by Wei et al. (2010), which reached $2.08 \mu \mathrm{g} / \mathrm{L}$. It is noticed that CP was detected only from January 2012 to April 2012 in which level of ammonia in raw water was higher than $1.5 \mathrm{mg} / \mathrm{L}$.

In comparison, Plant 1 has generally higher DBPs concentration than Plant 2. This is because Plant 1 has a larger reservoir than Plant 2 which means higher contact time leading to higher DBPs formation. Maximum average value of Plant 1 is higher than Plant 2 maximum average values. But about seasonal variation, THMs concentration increase in summer and spring, while they decrease in winter. The percentages of each compound in THMs value are very close in the two plants. Plant 1 results show higher $\mathrm{CH}$ concentration and $\mathrm{CH} / \mathrm{THMs}$ ratio than Plant 2. In the two plants, $\mathrm{CH} / \mathrm{THMs}$ ratios have the highest value in 
winter and the lowest value in summer. DCAN and TCP results of both plants are in agreement with each other. There is no observed seasonal variation for these compounds. CP was not found in plant 2 while found in $30 \%$ of samples of plant 1 due to high level of ammonia in plant 1 raw water in winter season.

\section{Correlation between DBPs and water quality parameters}

The DBPs concentration and speciation are affected by many water quality parameters (TOC level, $\mathrm{pH}$, bromide/ nitrite, etc.) and operating conditions (disinfectant type, dosage, reaction time). For chlorination, formation of THMs and HNMs generally increases with the increase of chlorine dose, contact time and NOM level (Song et al. 2010).

The rates of formation of most DBPs increase with increasing temperature. Water temperature was strongly correlated with THMs, while lower correlation was observed with $\mathrm{CH}$ and DCAN. But there was negative correlation between water temperature and TCP. In general, the rate of THM production increases with $\mathrm{pH}$. Formation of THM depends mainly on the last step of THM reaction pathway, which is base-catalyst as with the haloform reaction (Hong et al. 2007). A correlation $(r=0.23$, $0.37,0.29,0.33$, respectively) was obtained between THMs, DCAN, CH, TCP formation and $\mathrm{pH}$. A moderate correlation was obtained between DBPs formation and chlorine dosage. While negative correlation was obtained with residue free chlorine.

The DBPs are formed when the disinfectant reacts with NOM. TOC is one of the most widely used measures for quantifying the amount of NOM in water. In general, greater DBP levels are formed in waters with higher concentrations of TOC (USEPA 2006). A low correlation was obtained between DBPs formation and TOC, and a low negative correlation with a TOC removal.

\section{Conclusion}

- Samples of drinking water from the two plants, Edfina and Kom-Hamada, were analyzed for water quality parameters and Disinfection by-products (DBPs). The results indicated that the DBPs levels in all samples collected from October 2011 to September 2012 were generally below MCL set for these compounds in drinking water guidelines.

- Plant 2 has a higher maximum average $\mathrm{pH}, \mathrm{TOC}$ and turbidity than plant 1 .
- The maximum average TOC values were found in winter, while the minimum values were found in summer.

- Higher DBPs results were detected in spring and summer, while the lowest results detected in winter.

- Plant 1 show higher DBPs concentrations than plant 2 due to larger reservoir of plant 1 .

- Chloroform was the most abundant THMs species with a percentage up to $55 \%$.

- $\mathrm{CH} / \mathrm{THMs}$ ratios were ranged from ratio increase during winter and decrease in summer.

- CP detected only in the presence of high level of ammonia in raw water.

Open Access This article is distributed under the terms of the Creative Commons Attribution License which permits any use, distribution, and reproduction in any medium, provided the original author(s) and the source are credited.

\section{References}

APHA, AWWA and WEF (2005). Standard Methods for the Examination of Water and Waste Water. 21th ed. American Public Health Association, Washington, DC

Ates N, Kaplan SS, Sahinkaya E, Kitis M, Dilek FB, Yetis U (2007) Occurrence of disinfection by-products in low DOC surface water in Turkey. J Hazard Mater 142:526-534

Baytak D, Sofuoglu A, Inal F, Sofuoglu SC (2008) Seasonal variation in drinking water concentrations of disinfection by-products in IZMIR and associated human health risks. Sci Total Environ 407:286-296

El Shehawy R, Awad J (2012) Monitoring and modeling of fayoum distribution networks according to trihalomethanes formation. Civ Environ Res 2:59-68

EURACHEM (2000). CITAC guide number 4. Quantifying uncertainty in analytical measurement, 2nd edn. ISBN 0-948926-15-5

EURACHEM guide (1998). The fitness for purpose of analytical methods. A laboratory guide to method validation and related topics. ISBN 0-948926-12-0

Geriesh MH, Balke KD, EL-Rayes AE (2008) Problems of drinking water treatment along Ismailia Canal Province Egypt. J Zhejiang Univ Sci B 9:232-242

Golfinopoulos SK, Nikolaou AD (2005) Survey of disinfection byproducts in drinking water in Athens, Greece. Desalination 176:13-24

Hassan AAM, Benfenati E, Fanelli R (1996) Detection and quantification of trihalomethanes in drinking water from Alexandria. Egypt Bull Environ Contam Toxicol 56:397-404

Hong HC, Liang Y, Han BP, Mazumder A, Wong MH (2007) Modeling of trihalomethane (THM) formation via chlorination of the water from Dongjiang River (source water for Hong Kong's drinking water). Sci Total Environ 385:48-54

Hu J, Song H, Karanfil T (2010) Comparative analysis of halonitromethane and trihalomethane formation and speciation in drinking water: the effects of disinfectants, $\mathrm{pH}$, bromide, and nitrite. Environ Sci Technol 44:794-799

Koudjonou B, LeBel GL, Dabeka L (2008) Formation of halogenated acetaldehydes, and occurrence in Canadian drinking water. Chemosphere 72:875-881

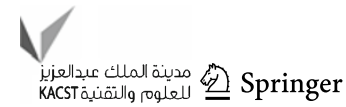


Lebel GL, Benoit FM, Williams DT (1997) A one-year survey of halogenated disinfection by-products in the distribution system of treatment plants using three different disinfection processes. Chemosphere 34:2301-2308

Ministry of Health (2007) Criteria for Potable Water. Egyptian Ministry of Health, Cairo

Othman AA, Rabeh SA, Fayez M, Monib M, Hegazi NA (2012) ElSalam canal is a potential project reusing the Nile Delta drainage water for Sinai desert agriculture: microbial and chemical water quality. J Adv Res 3:99-108

Richardson SD, Plewa MJ, Wagner ED, Schoeny R, Demarini DM (2007) Occurrence, genotoxicity, and carcinogenicity of regulated and emerging disinfection by-products in drinking water: a review and roadmap for research. Mutat Res 636: $178-242$

Song H, Addison JW, Hu J, Karanfil T (2010) Halonitromethanes formation in wastewater treatment plant effluents. Chemosphere 79:174-179

USEPA (1998). Disinfectants/disinfection by-products. Final rule. Federal Register, EPA, Washington, DC, 63(241):69390

USEPA (2001). National primary drinking water standards. United States Environmental Protection Agency, EPA 816-F-01-007
USEPA (2006). Initial distribution system evaluation guidance manual for the final stage 2 disinfectants and disinfection byproducts rule. EPA, Washington, DC, 815-B-06-002

USEPA method 551.1 (1995). Determination of chlorination disinfection by-products, chlorinated solvents, and halogenated pesticides/herbicides in drinking water by liquid-liquid extraction and gas chromatograph with electron-capture detection. Much, J.W., Hautman, D.P., Office of Research and Development, Washington, DC

Wei J, Ye B, Wang W, Yang L, Tao J, Hang Z (2010) Spatial and temporal evaluations of disinfection by-products in drinking water distribution systems in Beijing. China Sci Total Environ 408:4600-4606

WHO (2008). Guidelines for Drinking Water Quality. In: Recommendations, 3rd ed., vol. 1. World Health Organization, Geneva

Woo Y-T, Lai D, McLain JL, Manibusan MK, Dellarco V (2002) Use of mechanism-based structure-activity relationships analysis in carcinogenic potential ranking for drinking water disinfection by-products. Environ Health Perspect Suppl 110:75-87

Wright JM, Schwartz J, Dockery DW (2004) The effect of disinfection by-products and mutagenic activity on birth weight and gestational duration. Environ Health Perspect 112:920-925 